\title{
Optimization of Wastewater of Batik Buaran Pekalongan by Using Photocatalytic Membrane Bioreactor
}

\author{
Fahmi Arifan ${ }^{l}$, FS Nugraheni ${ }^{1}$, and Niken Elsa Lianandaya ${ }^{l}$ \\ ${ }^{1}$ Chemical Engineering Department, Vocational School, Diponegoro University, Semarang, Indonesia
}

\begin{abstract}
The purpose of this study is to determine the final COD concentration reduction by changing COD and MLSS concentration on the performance of submerged membrane bioreactor (MBRs) as a waste treatment of Batik in Buaran Pekalongan. The method is covers the process of seeding, the acclimatization process and the main process. Description of the process that we take an active mud from IPLT Buaran Pekalongan, then we analyze the sludge MLSS, MLVSS, COD, BOD, and TSS. After that we enter the active sludge in the bath nursery that has been given aerator (a tool for aeration) and made provision in the form of NPK nutrients and glucose at a ratio of 1:10. Activated sludge from the acclimatization process is inserted into the MBRs (membrane bioreactor submerged) that is equipped with an aerator. Then prepare influent(waste to be lowered concentration of COD). How, liquid waste of Batik Pekalongan Buaran COD diluted concentration of $10,000 \mathrm{mg} / 1$ and $15,000 \mathrm{mg} / 1$, and then inserted in influent tub. After that liquid waste of Batik Buaran Pekalongan influent flowed into Photocatalytic Membrane Bioreactor, of MPB effluent flowed into the tub (result).
\end{abstract}

\section{Introduction}

Nowadays, the development of technology in all fields to bring a considerable impact on human life. One negative aspect of these new technologies is the environmental degradation caused by the waste. Types of waste can be, among others, solids, liquids, and gas. Waste is very dangerous because it contains a high concentration of chemical substances, therefore it must be lowered levels of COD (Chemical Oxygen Demand) [1,2]. Process wastewater treatment with submerged membrane bioreactor, have many advantages over waste treatment with other membrane processes. It is seen from the standpoint of effectiveness and efficiency of the process itself is simple and automatic operating costs are also much smaller with better results.

Theoretically, the combination of activated sludge processing and submerged membrane will produce better processing performance than conventional activated sludge (sludge and clarifier) [3]. This is because the ability of the membrane filtration is not influenced by the characteristics biofloc formed. Membranes can be generally defined as a selective barrier between the two phases. Said selective here describe something that is typical of the membrane and the process by using a membrane, but did not explain matters related to the structure and function of the membrane itself. The membranes have different thicknesses. No structure or homogeneous. Transport of molecules across the membrane can be active or passive. Passive transport occurs because of differences in concentration, pressure, and temperature. Because of very varied shape and characteristics of the membrane, the membrane is carried classification. One classification, membrane divides into two parts, namely biological membranes and synthetic. Biological membrane is in the body of living creatures, as well as cell-cell life.

These membranes can be divided into the membrane life (living membrane), and the membrane inanimate (non-living membrane). Synthetic membranes can be divided into organic membrane (polymer) and inorganic Separation techniques contained in membrane technology there are two kinds of cross-flow system (crossflow) and passing flow (dead end). Cross flow (crossflow) is the flow of the bulk solution including the parallel flow on the membrane surface and only a few solutions left on the surface of the membrane. Named "crossflow filtration" for bulk flow immediately follow the permeate flow. While applied in this study is a "dead-end". The flow of dead-end, including the bulk solution flow across the membrane surface and bulk solution including the solids trapped on the membrane surface. As a consequence, the collected solids filtered continuously and form clogging the membrane surface. In a membrane bioreactor, SS concentration of the bulk solution, such as activated sludge, which has a high concentration on a dead-end where the separation is

\footnotetext{
Corresponding author: fahmiarifan80@gmail.com
} 
generally not possible due to the active sludge will form quickly clog the membrane $[4,5]$.

There are two configurations of membrane bioreactor (MBR) that: membrane of bioreactor located outside and submerged membrane bioreactor. In the configuration of external MBR, mixed liquor is pumped from the aeration tank to the pressurized membrane system located outside the bioreactor where suspended solids are retained and fed back into the bioreactor, while effluent penetrating the membrane. Membranes need in backwash periodically to remove suspended solids formed and accumulates and is chemically washed when the pressure becomes too high operational. So that high-quality effluent that can be achieved without depending on MLSS concentrations and deposition characteristics biofloc. Although there is still the possibility of the outbreak of microbial floc (biofloc) due to high shear stress caused by high crossflow velocity [6]. High energy recirculation pump which can be an obstacle. Submerged membrane separation activated sludge process is important in the treatment of wastewater, because it can overcome the problem of microbial lyses shear because high crossflow velocity. In a submerged MBR configuration, low-pressure membranes immersed in aeration tanks operated by vacuum pressure. The membrane is agitated by air bubble aeration system that can help prevent the accumulation of suspended solids on the membrane surface. Periodically submerged membrane and washed chemically in backwash when the operating pressure becomes too high. But does not require a circulating pump.

The use of a membrane allows the MBR operate without depending on the quality of the deposition of silt and eliminate the need clarifier. Consequently submerged MBR can typically be operated at MLSS concentration between 5000-40000 mg / L. MBR submerged in operation at the age of sludge exceeds forty days. Operational parameters submerged MBR is different than conventional biological wastewater systems. This study seeks to develop a modified activated sludge treatment that is more compact in terms of construction of the building through a particular configuration. That is, with the removal of the building after the building activated sludge clarifier. Clarifier used as a substitute for submerged membrane bioreactor installed activated sludge. With the modifications, this research tried to explore the factors that influence the combination of activated sludge and membrane submerged $[5,7,8]$. By trying some of the variables will be known whether the combination of activated sludge and submerged membrane is quite reliable and capable of overcoming the problems which arise in the ordinary activated sludge treatment. Research to be carried out include the initial experiments to test the efficiency of the membrane-based process and ultrafiltration process separately. The main experiment is done by combining both instruments. The material to be processed is wastewater of Batik Buaran Pekalongan. Membranes used an ultrafiltration membrane. By observing the performance of membrane reactors will be determined ultra filration operating parameters that affect the water purification process and will obtain optimum operating conditions. In this way an attempt to reduce the waste problem that happened lately.

\subsection{Aim}

To determine the final COD concentration reduction by changing the concentration of COD and MLSS on the performance of submerged membrane bioreactor (BMRt) as a waste treatment of Batik in Buaran Pekalongan

\subsection{Benefits of Research}

The benefits of this research are as follows:

a. Developed an alternative solution to conventional biological treatment Lumpur active, so that problems at the operational activated sludge process can be reduced as well as enhance the performance of activated sludge in biological wastewater treatment.

b. Studying the effect of variation of organic load (COD), a load of solids in the form of microorganisms concentration (MLSS) on the performance of the combination of activated sludge and submerged membrane.

Preliminary analysis of the wastewater Batik Buaran Pekalongan conducted to determine the BOD and COD waste or liquid. With this analysis it can be seen BODCOD concentration, temperature, $\mathrm{pH}$, and total solids. This data is used later to calculate the type and amount of nutrients need to be added and the conditioning phase of acclimatization microbes. For purposes of analysis, COD concentration is done with the titration method and MLSS, MLVSS determined by Standard Methods For Examination of waste and wastewater.

\section{Methods \\ 2.1 Seeding Phase}

Seeding is done by taking an active Lumpur obtained from domestic unit in aerobic wastewater. Activated sludge obtained from a waste management unit Stool (IPLT) Sukolilo Surabaya. To increase the MLSS, the active Lumpur obtained aerated and added glucose substrate and nutrient required. The amount of glucose addition estimated to be sufficient for microbial energy needs for growth and maintenance. At this stage, MLSS analysis carried up to $25000 \mathrm{mg} / \mathrm{l}$

\subsection{Acclimatization stage}

Microorganisms are the adjustment phase to the surrounding environment that can degrade organic material from the waste Batik Buaran Pekalongan. 


\subsection{Characterization Membrane}

To characterize the membrane to determine the permeability of the membrane. The feed solution that is used to characterize the membrane obtained from the mud that has acclimatized. Characterization of membrane also be obtained from the critical flux membranes used. To obtain the critical flux carried combinations using the technique of back flushing.

\subsection{Top Trial Phase}

Variables that are used to perform the main experiment are:

- Concentration of Microorganisms (MLSS): 15,000; 20,000 and 25,000 $\mathrm{mg} / 1$

- Organic Load (Concentration COD): 10,000 and $15,000 \mathrm{mg} / 1$

\section{Results And Discussion}

The process of seeding is done to increase the number of microorganisms present in activated sludge. In this case, the mud used is derived from the waste treatment plant sludge Buaran Pekalongan. Mud obtained came from the OD (Oxidation Dict) and clarifier. In the initial condition is known that the amount contained in the sludge MLSS of $11880 \mathrm{mg} / 1$, MLVSS of $6040 \mathrm{mg} / 1$, COD of $710 \mathrm{mg}$ / 1, BOD of $285 \mathrm{mg} / 1$, TSS of $5270 \mathrm{mg} / 1$, having a $\mathrm{pH}$ of 7.8 and the temperature is $270 \mathrm{C}$.

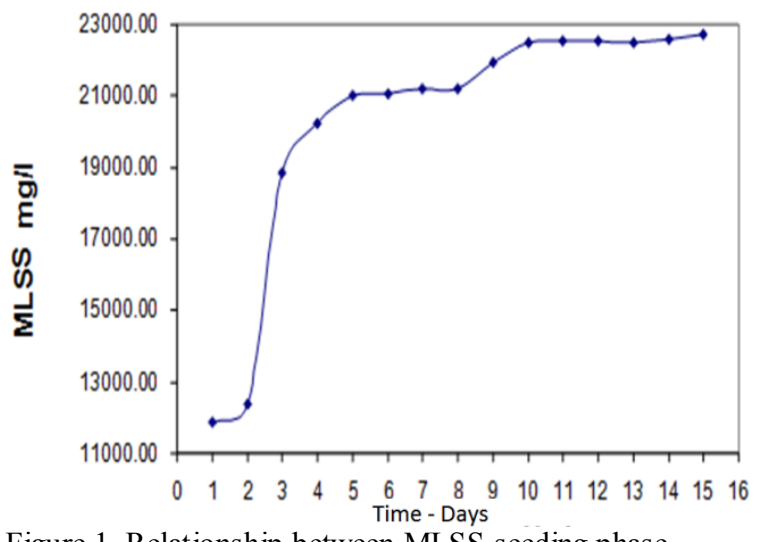

Figure 1. Relationship between MLSS seeding phase

The process of seeding sludge is done by mixing the activated sludge from the clarifier plus of OD, then after that added nutrients in sludge with aeration process. nutrients

given consists of two kinds of substances, namely NPK and Glucose with a ratio of 1:10. Giving nutrient done to increase the number of MLSS in the activated sludge. Seeding process is stopped when the amount of MLSS has been fulfilled. Here's a picture chart of the process of seeding.

\section{Conclusion}

This study can conclude:

- On the MLSS concentration of $15,000 \mathrm{mg} / 1$ for initial COD concentration of 10,000 and 15,000 mg / 1 , the concentration of COD can be derived is $98.36 \%$.

- In the MLSS concentration of 20,000 mg / 1 for initial COD concentration of 10,000 and $15,000 \mathrm{mg} / 1$, the concentration of COD can be derived is $98.41 \%$.

- In the MLSS concentration of 25,000 mg / 1 for initial COD concentration of 10,000 and $15,000 \mathrm{mg} / 1$, the concentration of COD can be derived is $98.42 \%$.

From the research results in decreased concentrations of COD by using active Lumpur with MLSS concentration of 15,000 mg / 1, 20,000 mg / 1, 25,000 mg / 1 for waste of batik in Buaran Pekalongan with COD concentration $10,000 \mathrm{mg} / 1$ and 15,000 mg / 1 obtained results inaccordance with the standard quality standard, so this study was successful, and can be applied to industries that treat their own wastes. Especially for waste Batik BuaranPekalongan.

\section{References}

1. Sugiharto. Dasar-dasarPengelolaanAir Limba. UI - Press,Jakarta (1987)

2. Surizal, Ariy., Whin Andreanne, Pengaruh COD Terhadap Kinerja Kombinasi Lumpur Aktif dan Membran terendam dalam mengolah Limbah Cair. ITATS Surabaya.

3. Cote, Piere., Herve Buisson, Charles Pound, Greg Arakaki. Desalination. 113.189-196. (1997)

4. Cicek,N., J. P. Franco, M. T. Suidan, V. Urbain, J. Manem. Wat Environ. Res.71,64-70. (1999)

5. Ghyoot. W, W. Verstraete,.Wat. Res. 34, 205215. (1999)

6. Chan A.H,. Water Science and Technology, 44, 187-195. (20010

7. M. Noguchi, Membrane-Cleaning Method for Membrane Bioreactor Process, Patents No. 7,422,689 B2, 2008

8. Metcalf \& Eddy., Watewater Enginering. Mc.Graw - Hill International Editor. (1991) 